中学校教科書におけるロ頭コミュニケーション を志向した活動の分析一第二言語習得研究に おけるタスク基準からの逸脱に焦点をあてて一

\title{
Analysis of Oral-Communication-
}

Oriented Activities in Junior High School

Textbooks: Focusing on Task Criteria

Proposed by Second Language Research

\section{福田純也}

Junya Fukuta

静岡大学

Shizuoka University

田村祐

Yu Tamura

名古屋大学

Nagoya University

栗田朱莉

Akari Kurita

矢作北中学校

Yahagikita Junior High School 
言語教育研究においては、学習者と教師、および学習者間の口頭コミュニケーション活 動についての重要性がこれまでも指摘されてきたが、日本の英語教育においても、授業 に口頭コミュニケーションを取り入れる必要性が徐々に認識されつつある。本研究では、 真正性の高い有意味な言語活動を促進するために作られたタスクの基準（e.g., Ellis, 2003; Ellis \& Shintani, 2014）を用いて、中学校教科書に含まれる口頭コミュニケーションを志向 する活動がどのような基準に合致しているかを分析した。そしてその結果をもとに、中学 校教科書に含まれている活動をそのまま用いることによって、学習者の言語スキル向上に 対してどのような結果が期待できるか、またはできないかについて、第二言語習得研究の 研究結果を参照しながら考察した。そして教科書に掲載されている活動の多くは、そのま ま用いると自発的に発話内容を言語化するプロセスを学習者が経験したり、言語習得上有 意義な意味交渉が起こつたりすることが期待できないことを示唆した。

In the field of language teaching research, the importance of meaningful interactions and oral communication activities has been pointed out repeatedly. In English language teaching in Japan, this importance has also been recognized by some teachers, although gradually. In this study we analyzed 3 textbooks used in Japanese junior high schools, referring to task criteria (e.g., Ellis, 2003; Ellis \& Shintani, 2014) that were developed for the purpose of promoting authentic meaningful communication. There were 4 task criteria: (a) the focus is on meaning, (b) there is a gap, (c) the learners rely on their own linguistic or nonlinguistic resources, and (d) learners' language use is not used to assess achievement. We examined whether or not the oralcommunication-oriented activities in the textbooks met these criteria. The textbook analysis indicated that the majority of the activities presented did not meet the task criteria. Among the four criteria, (c) - the learners rely on their own resources-was met the least. In most of the cases, linguistic resources such as conversation examples and lexical items were provided for the students, and the only thing the students needed to do was to use those resources. On the other hand, almost half of the activities met (b) - there is a gap-and this was the most easily satisfied criterion. We gave careful consideration to what kind of learner language proficiency development can be expected if classroom teachers use these communication-oriented activities as they appear in the textbook. In doing so, we considered the results obtained from previous SLA research. The fact that most of the activities in the textbooks did not meet the task criteria means that, if they are not modified appropriately, they would prevent language learners from engaging in voluntary grammatical encoding and negotiation of meaning. For example, as most of the activities did not meet criteria (c), the students can hardly experience grammatical encoding because they do not need to think about what linguistic form they should use to convey the meaning. Also, the fact that the focus of the task was not on meaning would result in a serious lack of meaningful negotiation, and therefore the students would miss precious opportunities to get comprehensible input through negotiation of meaning. In sum, the activities presented in the textbooks we analyzed were not enough to guarantee that the students would participate in negotiation of meaning and experience necessary cognitive processing during speaking, both of which are the essence of SLA. We do not propose that the activities should not be used or that they are useless. Rather, we believe that it is worthwhile to think of the communication-oriented activities 
with task criteria in mind in order to ensure the development of learners' language proficiency. In addition, teachers should modify the activities to enable the students to focus on meaning and to communicate using their own resources. The results of this study provide useful insights for teachers who want to make their classes more communicative and to have the students engage in meaningful conversation.

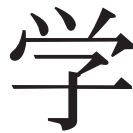

習者と教師、および学習者間の口頭コミュニケーションの重要性はこれま でもさまざまな研究により指摘されてきた。一つの流れとしては、応用言語 学者たちが試みた言語使用に関する能力の記述(e.g., Bachman \& Palmer, 1996; Canale, 1983; Canale \& Swain, 1980)に基づくもので、従来言語指導の際に重視 されてきた文法的能力 (grammatical competence) は言語能力の一部に過ぎないことを 強調するもの (e.g., 馬場, 1997; Brown, 2000)が挙げられる。この観点からの研究では、 統語・語彙・音韻的な知識を操作するスキルの養成だけではなく、言語が用いられる 社会的、文化的規則や慣習を理解し、その規則に即した「適切」な運用を行うことや、 コミュニケーションに何らかの障害 (communication breakdown)が生じたときに、さまざ まな方略をもちいてコミュニケーションを続ける能力なども言語運用能力に含め、これ らの能力をコミュニケーションを通して総合的に身につけることを重視する。

もう一つの流れとしては、文法的能力に関しても、口頭コミュニケーション活動を 通して実践的な運用スキルや知識をよりよく身につけることができるというものであ る。この観点からは、第二言語習得研究の認知的-相互交流的アプローチをとる研究 者 (cognitive-interactionist)たちが盛んに研究を行っている。例えば、Long (1985a) は 意味交渉を目的とした相互交流の中で生じる会話調整(相手の理解を確認したり、発 話の意味を確認したり、相手の理解を促すために発話を修正するなど)が、第二言語 習得における認知的プロセスを促すと主張した。また、第二言語の文法習得は、教師 の決めた指導順序どおりに進むわけではなく、学習者の内的シラバスにそって発達 することが第二言語習得研究者らによって主張され、自然なコミュニケーションや意 味理解活動の中で、適宜文法形式へ注意を焦点化させる活動 (focus on form) の有用 性が強調された (e.g., 和泉, 2009)。

このようなコミュニケーション活動の重要性は国内でも認識されつつある。コミュニ ケーション活動がどの程度、教室内活動における割合を占めるべきかについては未 だ答えの出ない問いではあるが、従来の受信型英語教育から発信型英語教育への 転換を実現すべきであるという観点から、アウトプットや、教師と学習者および学習 者間の対話、そしてそれらを含むコミュニケーションを重視した教授法の重要性が述 べられている(e.g., 佐藤, 2014)。

本研究では、口頭コミュニケーション活動に焦点をあてて、認知的-相互交流的アプ ローチ(cognitive-interactionist approach)に基づく第二言語習得研究を参照しつつ、中 学校教科書の分析を行う。

\section{先行研究における教科書分析}

日本における教科書のスピーキング活動やペア・グループワーク活動の分析はこれ までもいくつかの研究で行われてきており、例えば高校教科書におけるそれらの活動 がどのような特徵を持っているか (例えば「意見交換」・意思決定」など、どのような目 
標を念頭においた活動が多いか、活動に求められる結論は収斂型か、開放型かなど) を分析した研究 (荒金, 2015; 江草・横山, 2007)がある。これらの研究は、活動の特徵か らどのようなパフォーマンスが学習者に期待できるかを理論的に考察し、その結論と して、(a) 高校教科書では目標を達成するためにインタラクションを必要とするものが 少ない; (b) 流暢さの伸長にのみ効果が期待できる活動が多い; (c)市販されているテ キストほど正確さや複雑さへの効果が期待できない、といったことが示唆されている。

本研究も対象とする中学校教科書の分析では、平成18年版の旧課程教科書と、 平成24年版の新課程教科書の比較を行い、24年版におけるスピーキングやインタラ クション活動の数の増加が、パターンプラクティスのような活動の増加によることを示 した研究などがある(臼田・志村・横山・山下・中村, 2009; 臼田ほか, 2012)。これらの 研究では、近年増加したドリル的口語練習や語句を置き換えるだけの活動は、思考 力・判断力・表現力の育成という観点や、自らの体験や考えと結びつけて話すという た能力の伸長という観点からみて不十分であると指摘されている。

このようにこれまでの中学教科書の分析では、思考・判断・表現といったコミュニ ケーション能力に関連した高次の認知的能力を育むという観点から、教科書に含ま れる活動の不十分さが指摘されつつある。一方で、教室での授業実践の営みの目標 には、このような高次の認知的能力の育成だけでなく、言語の運用スキルを育成す ることや、そのために必要な知識を身につけることなど、言語のそのものの習得も当 然ながら含まれる。これらの言語運用スキルや知識という従来重視されてきた観点 は、中学教科書に含まれる活動を用いることで十分に育まれるといえるのだろうか。 前述の通り第二言語習得研究では、実践的な運用スキルや知識をよりよく身につ けるための口頭コミュニケーション活動はどのようなものかといった観点の研究がな されてきている。そこで本研究は新たな視点として、第二言語習得研究に基づき、 言語運用スキルや知識を十分に育むために必要な、真正性の高い有意味な言語活 動を促進する「タスク」の定義基準を採用し、中学校教科書に付属する口頭コミュニ ケーションを志向する活動の特徵を記述する。そして、第二言語習得研究の知見を 参照し、タスク基準からみた特徵に基づき、その活動によって促される(または促さ れない) と考えられる言語習得にかかわる認知プロセスをより詳細に検討する。

\section{第二言語習得における夕スク基準}

認知的-相互交流的アプローチを基盤にして、第二言語習得研究では「タスクに基 づく教授法 (task-based language teaching: TBLT)」が提唱されている。TBLTは、語 彙・統語・音韻などの言語的要素の定着を第一の念頭においた教授法とは異なる言 語習得観を持ち、設定された非言語的な目的を達成することを志向した課題である 「タスク」を基盤とした言語教授法である(詳細は松村，2012)。このタスクに学習者が 主体的に関与し、現実の言語使用と近い有意味な活動を行うことを通じて学習者は 言語を身につける。したがって、この教授法の基盤となる個々の「タスク」は現実の言 語使用と近い有意味活動を学習者に促すものである必要があり、さまざまな研究者 によってタスクの定義付けが試みられている(e.g., Ellis, 2003; Ellis \& Shintani, 2014; Long, 1985b; Skehan, 1998)。

どのようなものが夕スクであり、どのようなものがタスクといえないかという基準に 関してさまざまな研究者がその弁別的定義を提唱しているが、本稿では、多くの研究 
者に採用されているEllis（2003）の基準をさらに洗練化させた下記のEllis and Shintani (2014)の基準を採用することとする(訳は筆者らによる)。

1. 活動中の学習者の基本的な焦点は意味におかれる

2. 解決されるべき何らかのギャップが存在する

3. 自身の持つリソースによってタスクの遂行がなされる

4. 言語運用は手段であり、タスクが達成されたかどうかによって評価がなされる

上記1〜4の基準は、必ずしも完全に分割できる基準ではなく、それぞれが少しず つ関連し合って、当該活動がタスク的か否かを示している。

1.の基準は夕スクの大原則であり、ここでの「意味」の対義語は「形式」である。タス クにおいては、前述の通り現実に近い有意味な言語使用が重視されるため、語彙・統 語・音韻などの形式的な側面をその第一の焦点としない。学習者は現実世界での言 語使用者としての言語使用を求められる。その点で、例えば、過去形を用いることを目 的とし、“Did you〜”を使ってクラスメイトに質問をするような活動は、学習者が“Did you〜”という「表現」を使うことを目的としており、聞き出す「内容」に焦点があたってい るとは言えない。つまり、場面に埋め込まれたパターンプラクティスのような活動も、形 式を使用する訓練に主眼があるため、この基準においては夕スク的とはいえない。

2.の基準の「ギャップ」とは、コミュニケーションを行う中で生じる、対話者間の情 報量の違いや意見の相違を指す。例えば、ある地図を見ながら、話し手が聞き手に、 目的地までの道順を説明する課題を想定する。そこには話し手は目的地までの道順 を知っており、聞き手はそれを知らないという情報の差(=ギャップ)が生じている。学 習者はこのギャップを埋めようとすることで、コミュニケーションを取ろうとする。すな わち、このようなギャップは、コミュニケーションに必要性を与え、学習者を動機づけ るものであるといえる。また、このようなギャップは有意味な相互交流やその際に生じ るリキャストや意味確認などの働きかけ (interactional moves)が起こる必要条件とな る。埋めるべきギャップを埋めようとして、学習者は意味の理解ができない部分に対 して尋ねたり、自らの発話に関する誤りの訂正を行ったりし始める。このような相互交 流の働きかけが起こるか否かは、コミュニケーション活動を通した言語習得の効果に 大きく影響することが知られている(Kim, 2009, 2012; Mackey, 2007; Pica, 1992)。例 えば、ダイアローグが示されており、そのダイアローグを暗記して、ダイアローグ内の 語を入れ替えて対話練習をし、語を入れ替えても基本的に話の流れが変わらないよ うな活動は、学習者間にギャップがあるとは言えず、学習者が自発的に相互交流の 働きかけを伴う有意味なコミュニケーションを生じさせるような動機もないため、この 基準から逸脱することとなる。

3. の基準は、学習者がタスクを遂行する際に、与えられたモデルダイアローグや単 語・表現のリストなどの資料を参照するのみではなく自身のもつ知識や技能(リソース) を最大限利用して行う活動であるかどうかを問う。例えば電話でのやりとりを行う課題 で、学習者自身が表現を変え、やりとりの結末を変えることができるような選択が許さ れているとしても、必要となる会話表現が全て記載され学習者によって参照できる状 態になっている場合、何らかのコミュニケーションの目標が達成されたとしても、自身の もつリソースによってタスクが完遂されたとは言えない。自身のもつリソースによってタ スクを行うことは、換言すると、学習者自身のもつ知識と認知プロセスを十全に活用し 
てタスクに取り組むということでもある。学習者は口頭コミュニケーションの際には、口 頭で相手に自身の意見をわかりやすく伝えることが求められるが、そのような口頭産出 を行う際にはまず(a)自身が何を言うか、またどのように言うかという前言語的な概念 生成を行い、(b)その前言語的メッセージに対し、自身の知識にアクセスして語彙をあ てはめ統語・音韻情報を付与 (以下、このような心的な操作を「文法的エンコーディン グ」と呼ぶ)し、(c)調音装置を通して音声として言語を発する(Levelt, 1989)。このよう なプロセスのなかで、表現を学習者の知識の外にある(教科書などに準備されている) 資料から探し出し言語を発することの夕で達成される夕スクでは、学習者自身が第二 言語で何をどのように伝えるか、そしてその概念をどのような文法でエンコーディング するかという処理がほとんど行われないと考えられる。したがってそのようなタスクは上 記のプロセスのうち(a)と(b)が行われず、(c)のみがもちいられる。つまり、自然なコミュ ニケーションで必要とされる産出プロセスのほとんどが使用されず、プロセスが促進さ れることもないと考えられる。

最後となる4.の基準であるが、これは、特定の目標言語が適切に使用できたか どうかではなく、自然な言語コミュニケーションにおいて達成されるべき目標が達成 されたか否かによって評価がなされるべきであるというものである。行動志向的な CAN-DOリス卜を想定すると理解しやすいが、例えば「昨日あったできごとを、ぺアの 相手に伝えることができる」というものを教師がタスクの評価基準の一つとして採用 し、それが達成されたかどうかで評価を行うと「言語外の評価」が達成されたこととな る。逆に、「過去形を適切に用いて、昨日あったできごとを話し合うことができる」とい うのは、過去形という言語的特徵を参照した評価基準となり、タスクの基準からは外 れることになる。言語を参照した基準を採用しないのは、そのような基準を用いること で学習者が「間違えないように言語を使用する」ことを心がけることにより、意味中心 というタスクの原則が破綻してしまうことを防ぐためである。また、過剩な正確性の重 視は、「使える言語項目」のみを使うという、言語使用の回避につながる。学習者が過 剰に回避行動を行うと、新たに覚えた言語項目の自発的使用を抑圧してしまうことに もなり、言語習得上、望ましくないといわれている(e.g., Skehan, 1998)。

上記の基準は、どのようにすればコミュニケーション活動が現実世界に近い、有 意味で真正性の高い活動となるかという、言語教師の疑問に対して一定の答えを示 している。TBLTにおいては、以上の基準によって定義されたタスクをシラバスの軸と し、授業をデザインしていくが、この基準は、TBLTを採用しないコミュニケーション 活動を展開する際にも有用である2。コミュニケーションを取り入れた英語授業の重 要性が叫ばれる中、中学校教科書がこの基準にどの程度合致し、どの程度逸脱して いるかを示すことで、その教科書の活動を「そのまま」採用することにより得られる効 果、および期待できない効果について考察することができる。その上で、英語教師が どのように授業にコミユニケーション活動を取り入れ、展開するかに対して有用なヒン トが提供できると考える。

\section{方法}

\section{分析対象}

分析対象となったのは、日本全国における教科書採用数として上位三位に入る 『New Horizon(東京書籍)』、『Sunshine(開隆堂)』、そして『New Crown(三省堂)』 
である3。それぞれ 1 年生用から 3 年生用まで3冊に分かれているため、計9冊が分析対 象となった。本研究の目的は、教科書に掲載されている口頭コミュニケーションを志 向した活動が夕スクの基準にどの程度合致・逸脱しているかを分析することである。 したがって、教科書中に口頭コミュニケーションを促す指示(「ペアで話し合いましょう」 「意見交換しましょう」など)のある活動を広く「口頭コミュニケーションを志向した活 動」と定義し、それらを全て抽出した。抽出された活動の数は、327 (New Crown: 85, Sunshine: 165, New Horizon: 77)であった。

\section{分析方法}

抽出された活動をそれぞれ、上記のタスク基準 4つの観点からコーディングした。 コーディングは上記の観点と、Erlam(2016)のコーディング基準を改定したものに基 づきおこなった(表1)。このコーディング基準における問いの2つともに合致した場合、 当該基準が満たされていると判断した。この基準に基づく分析の信頼性を検討する ため、抽出された活動全体における1割について筆者ら3人の一致率を算出した。そ の結果、3者の一致率は84.5\%であった。不一致箇所を全て議論を通じて解消したの ち、分析対象となった活動すべてを3人で分担してコーディングした。

\section{表1. タスクのコーディング基準 (Erlam, 2016, p. 288を改定)}

基準を満たすための問い
基準を満たす際に

期待される答え

1 基本的な焦点は意味にある

学習者は夕スクにおいて言語学習者としてではなく言

はい

語使用者として機能することを求められるか

学習者が自発的に概念化したメッセージをエンコーディン グまたはデコーデイングすることが学習者の夕スク遂行中

はい

の主な焦点であり、言語形式でないか

2 何らかのギャップが存在する

コミュニケーションが起こつた結果そのギャップは解消

はい されたか

コミュニケーションの結果として、タスク遂行前は学習 はい 者自身が知らなかつた発見があるか

3 自身の持つリソースによって遂行される

学習者がタスクを遂行する際に必要な言語形式や表現 を教授されるか

いいえ

学習者は既に知っている表現を用いる機会が保障され ているか 
$\begin{array}{ll}\text { 基準を満たすための問い } & \text { 基準を満たす際に } \\ & \text { 期待される答え }\end{array}$

4 言語外の結果によって達成評価がなされる

言語はその目的としてではなく目的を達成するための はい

手段として使用されるか

タスクが達成されたか否かはタスクが完了したかどうか はい

で判断されるか

コーディングの際、コーディング基準に加え特に注意を必要とした点として、以下 の3点が挙げられる。まず、意味への焦点という点では、相手の発話が予想できず、 それに対する答えを事前に準備することができないような活動を、意味交渉ありと判 断し、意味への焦点を判断する材料として加えた。逆に、相手がどのような応答をし ても会話の流れが変わらないような、モデルに沿つた発話を求める課題は意味交渉 なしとした。

次に、ギャップの有無の観点では、教科書に答えの候補があるかどうか、またそれ を使用するだけで活動が完遂できるかという点と、コミュニケーションの結果として得 られる情報が学習者にとって新しいものであるかという点を考慮し、これらを満たした 場合はその活動にはギャップがあると判断した。例えば、ペアで「落とし物を拾って持 ち主に渡す」というコミュニケーションをモデルに沿って行うという活動はギャップがあ るとは判断できない。

最後に、言語外の評価という観点に関しては、文法による評価を行う指示 (過去形 を正しく用いて会話をするなど) 以外にも、コミュニケーションの結果として得られた情 報をもとに並び替えをする、表を作る、メモを取るといった活動がコミュニケーション活 動の後に位置づけられているかどうかを重視し、これらを基準にタスクが達成できたか 否かを判断できるといった場合は、言語外の評価という基準を満たしていると判断し た。

\section{結果}

表2に4つの基準を満たした活動の数と、全体の活動に占める割合を示した。ま た、表3には基準が満たされたコミュニケーション活動の数と割合を学年ごとに示し ている。教科書ごとに各基準の達成度合いは異なるが、全体として、学年が上がる ごとにコミュニケーション活動の数自体が減少していく傾向があることがわかる。コ ミュニケーション活動の総数でみていくと、Sunshineに掲載されている活動の総数は 165であり、New Crownの85と New Horizonの77を約2倍も上回っている。このことか ら、Sunshineには量的には豊富な口頭産出言語活動が掲載されていることがうかがえ る。しかしながら、4つのそれぞれの基準を1つでも満たしたコミュニケーション活動の 数の合計をみると、New Crownは119、Sunshineは94となり、むしろSunshineのほうが 少ない。New Crownはコミュニケーション活動の総数が85であることを考えると、1つ の活動あたりが満たす基準の数が1以上であることがわかる。一方で、New Horizon 
はコミュニケーション活動の総数が3つの教科書の中で最も少ない上に、基準の達成 数も最も少ない。

さらに詳しく各基準の達成度合いをみていくと、New Crownは4つの基準の中で、 学習者自身のリソースで活動に取り組ませるという基準は低いものの、活動に何らか のギャップが存在するという観点は7割近い活動がその基準を満たしていることがわ かる。また、活動の達成を言語使用以外の観点で評価するという基準も、半数近い活 動がその基準を満たしている。意味中心の活動であるかという点では、全体の $20 \%$ の活動がこの基準を満たしている。これは、決して高いものであるとは言えないもの の、SunshineやNew Horizonよりも遥かに高い割合である。

New Horizonは上記したように、口頭コミュニケーションを志向した活動が3つの教 科書のうちで最も少なく、基準の達成数の合計も最も少ない。それだけでなく、学年 を追うごとにインタラクティブな活動の代わりにパターンプラクティス的な口頭練習 が増加していくという傾向もみられた。その結果として、学年が上がるにしたがって 口頭コミュニケーションを志向する活動の数が著しく減少していることがわかる (表3）。4つの基準の中でも最も達成率が高いのはギャップの基準であり、この傾向 は全体の傾向と一致している。他の3つの基準はどれも1割に満たないが、特に深刻 なのはリソースの観点だろう。つまり、学習者が自ら発話内容を考え、それを表現す る言語形式を選択し、そして発話をするという活動がまったく揭載されていないとい える。そしてSunshineは、傾向としてはNew CrownとNew Horizonの中間に位置しつ つも、パーセンテージで比較すると概ねNew Horizonと同様の特徵が見られる。

\section{表2. 全教科書の達成数 (カッコ内はパーセント)}

\begin{tabular}{lrrrrrrrr}
\hline & \multicolumn{2}{c}{ New Crown } & \multicolumn{2}{c}{ Sunshine } & \multicolumn{2}{c}{ New Horizon } & \multicolumn{2}{c}{ 総合 } \\
活動 & 基準の達成数 & 基準の達成数 & 基準の達成数 & 基準の達成数 \\
\hline 意味 & 17 & $(20.0)$ & 11 & $(6.0)$ & 2 & $(2.6)$ & 30 & $(9.2)$ \\
ギャツプ & 58 & $(68.2)$ & 60 & $(36.3)$ & 23 & $(29.7)$ & 141 & $(43.1)$ \\
リソース & 3 & $(3.5)$ & 5 & $(3.0)$ & 0 & $(0.0)$ & 8 & $(2.4)$ \\
達成評価 & 41 & $(48.2)$ & 18 & $(10.9)$ & 4 & $(5.2)$ & 63 & $(19.3)$ \\
基準の達成数の & 119 & & 94 & & 29 & & 242 & \\
合計 & & & & & & & & \\
活動総数 & 85 & & 165 & & 77 & & 327 & \\
\hline
\end{tabular}

注. カッコ内のパーセンテージは、(各基準を満たした活動数／活動総数) $\times 100$ で計算されたも のである。意味:基本的な焦点が意味にある。ギャップ:解決されるべき何らかのギャップがある。 リソース:自身の持つリソースによつてタスクの遂行がなされる。達成評価:タスクが達成されたか どうかによつて評価がなされる。 
表3. 全教科書の学年ごとの達成数 (カッコ内はパーセント)

\begin{tabular}{|c|c|c|c|c|c|c|c|c|c|}
\hline \multirow{2}{*}{$\begin{array}{l}\text { 学年 } \\
1 \text { 年 }\end{array}$} & \multirow{2}{*}{$\begin{array}{l}\text { 活動 } \\
\text { 意味 }\end{array}$} & \multicolumn{2}{|c|}{$\begin{array}{c}\text { New Crown } \\
\text { 基準の達成数 }\end{array}$} & \multicolumn{2}{|c|}{$\begin{array}{c}\text { Sunshine } \\
\text { 基準の達成数 }\end{array}$} & \multicolumn{2}{|c|}{$\begin{array}{l}\text { New Horizon } \\
\text { 基準の達成数 }\end{array}$} & \multicolumn{2}{|c|}{$\begin{array}{c}\text { 総合 } \\
\text { 基準の達成数 }\end{array}$} \\
\hline & & 5 & (16.1) & 2 & (2.8) & 0 & $(0.0)$ & 7 & (4.6) \\
\hline & ギャップ & 21 & (67.7) & 30 & $(42.3)$ & 11 & $(21.6)$ & 62 & (40.5) \\
\hline & リソース & 0 & $(0.0)$ & 4 & (5.6) & 0 & $(0.0)$ & 4 & (2.6) \\
\hline & $\begin{array}{l}\text { 達成評 } \\
\text { 価 }\end{array}$ & 11 & (35.5) & 18 & $(25.4)$ & 1 & (2.0) & 30 & (19.6) \\
\hline & $\begin{array}{l}\text { 基準の達 } \\
\text { 成数の } \\
\text { 合計 }\end{array}$ & 37 & & 54 & & 12 & & 103 & \\
\hline & $\begin{array}{l}\text { 活動総 } \\
\text { 数 }\end{array}$ & 31 & & 71 & & 51 & & 153 & \\
\hline \multirow[t]{6}{*}{ 2年 } & 意味 & 9 & $(32.1)$ & 4 & (6.9) & 0 & $(0.0)$ & 13 & (12.9) \\
\hline & ギャップ & 19 & (67.9) & 16 & $(27.6)$ & 8 & (53.3) & 43 & (42.6) \\
\hline & リソース & 2 & (7.1) & 1 & (1.7) & 0 & $(0.0)$ & 3 & (3.0) \\
\hline & $\begin{array}{l}\text { 達成評 } \\
\text { 価 }\end{array}$ & 13 & (46.4) & 0 & $(0.0)$ & 0 & $(0.0)$ & 13 & (12.9) \\
\hline & $\begin{array}{l}\text { 基準の達 } \\
\text { 成数の } \\
\text { 合計 }\end{array}$ & 43 & & 21 & & 8 & & 52 & \\
\hline & $\begin{array}{l}\text { 活動総 } \\
\text { 数 }\end{array}$ & 28 & & 58 & & 15 & & 101 & \\
\hline \multirow[t]{6}{*}{ 3年 } & 意味 & 3 & (11.5) & 5 & (13.9) & 2 & $(18.2)$ & 10 & (13.7) \\
\hline & ギャップ & 18 & (69.2) & 14 & $(38.9)$ & 4 & $(36.4)$ & 36 & (49.3) \\
\hline & リソース & 1 & (3.8) & 0 & $(0.0)$ & 0 & $(0.0)$ & 1 & (1.4) \\
\hline & $\begin{array}{l}\text { 達成評 } \\
\text { 価 }\end{array}$ & 17 & (65.4) & 0 & (0.0) & 3 & (27.3) & 20 & (27.4) \\
\hline & $\begin{array}{l}\text { 基準の達 } \\
\text { 成数の } \\
\text { 合計 }\end{array}$ & 39 & & 19 & & 9 & & 67 & \\
\hline & $\begin{array}{l}\text { 活動総 } \\
\text { 数 }\end{array}$ & 26 & & 36 & & 11 & & 73 & \\
\hline
\end{tabular}

注. カッコ内のパーセンテージは、(各基準を満たした活動数／活動総数) $\times 100$ で計算されたも のである。意味:基本的な焦点が意味にある。ギャップ:解決されるべきなんらかのギャップがあ る。リソース:自身の持つリソースによってタスクの遂行がなされる。達成評価:タスクが達成され たかどうかによって評価がなされる。 
全体でみると、最も達成されやすい基準はギャップであり、最も達成されにくい基 準は学習者のリソースであった。この全体の傾向とは異なる傾向を示した教科書はな かったため、これは3つの教科書に共通の傾向であるといえるだろう。

次に、それぞれの基準を満たしているか否かという観点を、基準の組み合わせで 見ていく。表4には、全教科書、また教科書ごとに、どのようなタスク基準の組み合わ せの数が多いかを示した。

まず一見して、どの教科書も4つの基準すべてを満たしていない活動の割合が1番 多いことがこの表からわかる。New Crownではそのような活動は全体の3割ほどにとど まったものの、この傾向は特にSunshineとNew Horizonに顕著であり、Sunshineで約6 割、New Horizonで約7割がタスク基準の全てに逸脱している活動であった。

上述のように、もつとも達成されやすい基準はギャップであったため、いずれの教 科書も、第2位以下の組み合わせではギャップの基準に関してはほとんど満たしてい ることがわかる。また、ギャップのある活動には、達成評価として言語外の評価が可 能なものが付随しやすいこともわかる。しかしながら、ギャップのある活動であって も、意味中心の基準やリソースの基準を満たしている活動の割合は非常に少ないこと が分かる。ギャップの基準をもつともよく満たしているNew Crownであっても、リソース とギャップの基準を満たす活動は全体の $2.4 \%$ しなく、Sunshineもこの2つの基準を 満たす活動は1.8\%と、きわめて限られている。New Horizonは、ギャップのある活動こ そあれど、リソース基準を満たす活動はなかったため、ギャップがありなおかつ学習 者が自身のリソースを用いて遂行するという活動は見られなかった。

\section{表4.4つの夕スク基準の組み合わせ頻度 (上位5位)}

\begin{tabular}{lcrrcccc}
\hline 教科書 & 順位 & 頻度 & 割合 & 意味 & ギャップ & リソース & $\begin{array}{c}\text { 達成 } \\
\text { 評価 }\end{array}$ \\
\hline 総合 & 1 & 183 & $54.6 \%$ & $\times$ & $\times$ & $\times$ & $\times$ \\
$n=335$ & 2 & 69 & $20.6 \%$ & $\times$ & $\bigcirc$ & $\times$ & $\times$ \\
& 3 & 40 & $11.9 \%$ & $\times$ & $\bigcirc$ & $\times$ & $\bigcirc$ \\
& 4 & 15 & $4.5 \%$ & $\bigcirc$ & $\bigcirc$ & $\times$ & $\bigcirc$ \\
& 5 & 10 & $3.0 \%$ & $\bigcirc$ & $\bigcirc$ & $\bigcirc$ & $\times$ \\
\hline New Crown & 1 & 25 & $29.4 \%$ & $\times$ & $\times$ & $\times$ & $\times$ \\
& 2 & 24 & $28.2 \%$ & $\times$ & $\bigcirc$ & $\times$ & $\bigcirc$ \\
& 3 & 17 & $20.0 \%$ & $\times$ & $\bigcirc$ & $\times$ & $\times$ \\
& 4 & 13 & $15.3 \%$ & $\bigcirc$ & $\bigcirc$ & $\times$ & $\bigcirc$ \\
& 5 & 2 & $2.4 \%$ & $\bigcirc$ & $\bigcirc$ & $\bigcirc$ & $\bigcirc$ \\
\hline
\end{tabular}




\begin{tabular}{lcrrcccc}
\hline 教科書 & 順位 & 頻度 & 割合 & 意味 & ギャップ & リソース & $\begin{array}{c}\text { 達成 } \\
\text { 評価 }\end{array}$ \\
\hline Sunshine & 1 & 105 & $63.7 \%$ & $\times$ & $\times$ & $\times$ & $\times$ \\
$n=165$ & 2 & 32 & $19.4 \%$ & $\times$ & $\bigcirc$ & $\times$ & $\times$ \\
& 3 & 17 & $10.3 \%$ & $\times$ & $\bigcirc$ & $\times$ & $\bigcirc$ \\
& 4 & 9 & $5.5 \%$ & $\bigcirc$ & $\bigcirc$ & $\times$ & $\times$ \\
\multirow{2}{*}{ New Horizon } & 1 & 53 & $68.8 \%$ & $\times$ & $\times$ & $\times$ & $\times$ \\
$n=79$ & 2 & 20 & $26.0 \%$ & $\times$ & $\bigcirc$ & $\times$ & $\times$ \\
& 3 & 2 & $2.6 \%$ & $\bigcirc$ & $\bigcirc$ & $\times$ & $\bigcirc$ \\
& 4 & 1 & $1.3 \%$ & $\times$ & $\bigcirc$ & $\times$ & $\bigcirc$ \\
& 4 & 1 & $1.3 \%$ & $\times$ & $\times$ & $\times$ & $\bigcirc$ \\
\hline
\end{tabular}

注. 4つの基準におけるメは基準を満たしていないこと、○は基準を満たしていることを表す。意 味:基本的な焦点が意味にある。ギャップ:解決されるべきなんらかのギャップがある。リソース: 自身の持つリソースによってタスクの遂行がなされる。達成評価:タスクが達成されたかどうかに よって評価がなされる。

\section{考察}

分析の結果、対象となった 3 冊の教科書に掲載されていたコミュニケーションを志向 する活動は、全体の半数以上が夕スク基準の全てから逸脱している活動であることが示 された。これは、教科書に掲載されている口頭コミュニケーションを志向する課題のほ とんどが、ペアでスキットを読み上げたり、ダイアローグ内の表現を入れ替えたりするこ とのみが求められるような課題であったことによる。New Crownについてはタスク基準 のすべてを逸脱している活動は全体の3割弱にとどまっていたが、やりとりの焦点が意味 にある活動や、学習者が自分のリソースを用いて課題を遂行するといった性格の活動は 極めて少なく、スキットや表現を入れ替えて発話する活動が大部分を占めていた。つま り、口頭コミュニケーションを志向する課題でも、そのほとんどがペアで行う音読かその 延長線上に位置づけられるものであるといえる。ただし音読活動そのものに関しては、 「有意味な口頭コミュニケーション」以外の目的をもって実施されることもあり、その活 動自体が即座に悪いものというわけではない。例えば、音読活動は学習者が「英語を声 に出す」という抵抗感を軽減するという調査もある(Morioka, Tsumura, \& Fukihara, 2015)。 また「全ての基準から逸脱」とされた活動の少なかったNew Crownにみられる顕著な特 徵として、「全ての基準から逸脱」に該当する活動は、すべて“skit”という、ダイアローグ を覚えて声に出すセクションであったことが挙げられる。このような活動を「英語を声に 出す抵抗感の軽減」や、「発音の練習」などといった目的をもって行うことの意味は、この 結果によって否定されないことは付記しておかねばならない。

次に、全体の傾向として「自身の持つリソースによって遂行される」という基準は もつとも満たされにくいことが示された。つまり、教科書に口頭コミュニケーション活動 が出てきたとしても、その活動は事前に用意された言語項目をそのまま運用すれば 
達成できるものであった。ほとんどを占めるケースとして、活動の説明や必要な絵な どが示されたのち、そのページの下部もしくは横に、生徒が発話すべき言語項目や表 現が「すべて」列挙されており、生徒がすべきことはその表現の一部を変えて(もしく はそのまま)発話するということであった。このリソースに関する基準を満たすのがもつ とも難しいという結果は、研修を受けた語学教員が作成した夕スクを本研究と同様の 観点から評価したErlam(2016)の結果とも一致するものである。

既に記したように、このようなタスクでは、学習者が自然な口頭コミュニケーション のために発話を行う最初の段階、すなわち自身が第二言語で何をどのように伝える かを考え、次にどのような文法でエンコーディングするかという処理がほとんど行わ れないと考えられる。学習者の視点から換言すると、学習者が自身で言う内容を生成 し、その内容をどういった言語形式で表せばよいか自発的に考える機会がほとんどな いということである。このような課題をそのまま用いることは、学習者の口頭コミュニ ケーションにおける自発的発話を訓練するという意図からは外れたものとなる。

また、「何らかのギャップが存在する」という基準を満たしているものは、本研究が 採用した基準の中では満たされているものが最も多かった。これは、口頭コミュニケー ションを行うに際して、そのやり取りを動機づけるためにギャップは最低限必要にな るものであるためではないかと考えられる。特に興味深い特徵として、New Crownに 掲載されている活動の65\%近くが、この「ギャップが存在する」という基準を満たしてい た。New Crownは、自己表現活動が多く取り入れられており、口頭コミュニケーション の際に自身が持つ相手の知らない内容(自分の嗜好など)を伝えることを求めるものが 多いため、このような傾向が見られたと考えられる。また、New Crownl自己表現活動 ののちに「メモを取る」、「表を完成させる」など、言語外の達成評価を採用しているも のが多かった (28.2\%)ことがその特徵として挙げられる。これらの特徵は、他の活動を より真正性の高い活動にする際に参考になる点であるといえる。

しかし、全体的に見て「何らかのギャップが存在する」という基準を満たしている活 動も、上記の「自身の持つリソースによって遂行される」が組み合わせとして満たされて いないものがほとんどであった。もともと、ギャップを作る大きな理由の一つとしては、 前述のように学習者が自発的に相互交流の働きかけを生じさせるように動機づけるこ とであったが、課題によって必要とされる表現が全て教科書に記されており、相互に 何が表現されるかがわかっている条件では、聞き手が発話の不明瞭な部分を確認す るために聞きなおしたり、話し手が意味を伝えるために言い換えたりなどといった働き かけの発生はあまり期待できないといえよう。

New Crownに掲載されている自己表現活動において達成評価を言語外で行える 構成になっているタスクが多いのは前述の通りであるが、Sunshineに関しては言語 外の達成評価がみられたのは中学校1年生の教科書に掲載されている活動のみで あった。またNew Horizonに関しては、口頭コミュニケーションを促す課題の数自体 が他の教科書と比較して少ない。また分析結果をみてわかるように、Sunshineにおい ては 8 割以上、New Horizonにおいては95\%以上が外的資料を参照しながら「その 日に学習する言語項目を使った文を声に出す」といった性格の強い課題であり、その ような課題においては言語外の達成評価を採用することが難しい。このような場合、 学習者に真正性の高い有意味な口頭コミュニケーションの機会を提供するには、教 科書に揭載されている課題を大幅に改定するか、教師が自らそのようなタスクを用 意しなければならない。 
また全体の傾向として、学年が上がるごとに口頭コミュニケーションの数が低下し ていく傾向がみられた。この結果は筆者らの直感に反するものであった。なぜなら、「 自身の持つリソースによって遂行される」という基準が満たされていないのは、教科書 が「英語学習初期の段階では、学習者自身がもつ言語的リソースが限られているた め、自然な口頭コミュニケーションができない」という教師の不安を反映しているため ではないかと考えたためである。しかし、そうであれば、英語のスキルが向上する高 い学年になるにつれて、このような口頭コミュニケーションを志向する活動の数はむ しろ増加していくはずである。口頭コミュニケーションを志向する活動の数が減少す るということは、その他の文法説明や読解活動に多くの分量が割かれているというこ とである。このことは、1・2年次にはいわゆる「教科書本文」が会話調であることが比 較的多いことに比べて、3年次の教科書では物語文や説明文が教科書本文として登 場する頻度が高いことからも裏付けられる。このことは、日本における教科書では、口 頭コミユニケーションを志向する活動が英語の運用スキル習得という観点からはあま り重視されていない可能性を示している。

では、教師は教科書に掲載された言語活動をどのように改変すれば、第二言語習 得の観点から有益とされる文法エンコーディングの機会を保障し、さらに学習者同士 の意味交渉を促すような活動を取り入れることができるのであろうか。この点を、本 研究が参照したタスクの定義とその基準の観点から考察してみたい。

まず、言語使用以外の達成評価に関しては、New Crownでしばしば用いられてい た、「メモを取る」「表を作成させる」といった活動を追加することが挙げられる。表に 埋めたことについて、ペアまたはグループワークの後に教室全体でシェアしたり、表 やメモを元にその後文を書かせるようにしたりするなど、表を埋めることに意味をも たせることが重要である4。

次に、意味への焦点である。これは、単なる単文応答以外の要素を付与するような 指示を加えることが1つの方法として考えられる。例えば、ただ過去に起こったことにつ いて質問し、それに答えるのタではなく、相手の答えに応じた発話を投げ返すことを 学習者に求めるのである。これは「プラスワンダイアログ」とも呼ばれ、実際に教室で活 用している教師も多いかもしれない。こういった仕掛けを用意することで、相手の応答 に対してその場で自分の伝えたいことを概念化し、それを文法エンコーディングすると いう作業を学習者は求められることになる。ただし、単に質問をすることを目的とする のではなく、言語使用以外の達成評価の観点も鑑み、会話を広げることによって達成 できるような別の目標を設定しておくことも重要である。

また、相手が何を言うか予想がつかない—実際のコミュニケーションではそういつ た場面がむしろ普通であるが—状況における発話場面では、相手の発言の意味を確 認したり、または理解できなかった場合に聞き返したり、理解されなかった際に発言 を修正したりといつた意味交渉が起こりやすいといえる。このような理解の確認や聞 き返し、発言の修正などは、コミュニケーション活動時に限らず英語の授業の中で教 師が積極的に英語を使いながらモデルを示すことが望ましい。場合によっては、理解 ができなかったときや相手の発言の意味を確認したいときに使う表現を補助資料と して学習者に渡しておき、活動の中で場面に応じて使用できるような手助けをするこ とも考えられる。

最後に、本研究の調査結果から最も満たされにくい基準と判断された「自身のもつ リソースによって遂行される」について述べる。これについては、教科書に揭載されて 
いる語彙やフレーズの情報をできるだけ参照させないようにすることが必要である。 例えば、規則変化動詞の過去形 (e.g., played, watched, visited)の産出を狙った活動が あったとしよう5。ここで、 played a video game, watched a movie, visited a museumといっ た語句をあたえてしまっては、学習者が活動中に行うことはここに書かれた語句をス ロット（I__）にあてはめて産出するだけであることは予想がつく。それでは、概念化 と文法エンコーディングのプロセスを学習者が経験することができない。したがって、 例えば動詞の原形のみを与えて (e.g., play, watch, visit)、「何を作ったか」「どこに行っ たか」「なにを食べたか」などは学習者に自由に考えさせてみてはどうだろうか。こう することで、“What did you do yesterday?”之聞かれた学習者が例えば「昨日友だちと ゲームをした」ということを伝えたいと思ったとき、それをどうやって英語で表現する かの文法エンコーディングプロセスを行う機会を保障することができる。

この「自身のもつリソースによって遂行される」という観点は、ともすれば「教師は夕 スク遂行に必要となる言語形式を教えてはならない」読み替えられてしまうこともあ る。しかしながら、これは誤解である。あくまで、「事前に」教えてはならないのであつ て、タスク遂行中に学習者が自分で表現したいことと、自分が表現できることのギャッ プに気づいたあとで (noticing the gap)、タスク遂行に有効な言語形式を教師が与えて あげればよいのである(e.g., Swain, 1993)。

以上、活動改変の例として、タスクの定義と基準をもとにいくつかの提案をした。た だし、これはあくまで一つの提案にすぎず、これだけが唯一の答えではないことは申 し添えておかねばならない。教師自身が目の前の学習者をよく観察し、彼らに適切な 活動を考えることが重要であることは、疑いのないことである。

\section{結論}

本研究は、学習者と教師、および学習者間の口頭コミュニケーションを志向する活 動の重要性が徐々に認識されつつあることを踏まえ、日本における中学校教科書に揭 載されている口頭コミュニケーションを志向した課題がどのような特徵を持つか、第 二言語習得研究の知見を援用しつつ調査することを目的とした。そのため本研究で は、Ellis and Shintani(2014)の示した「基本的な焦点は意味にある」、何らかのギャッ プが存在する」、「自身の持つリソースによって遂行される」、「言語外の結果によって 達成評価がなされる」という4 4 つ基準に照らして 3 種類の教科書の特徵を分析した。

結果として、教科書に掲載されている口頭コミュニケーションを志向する活動は、教 科書に掲載されているダイアローグを読み上げるか、付記されている表現を選んで入 れ替えることによって達成される課題が最も大きな割合を占めることが示された。この ことは、教科書を教師が自ら改変せず用いると、学習者が自身で言う内容を自発的に 考え、その内容をどういった言語形式で表せばよいかという文法的エンコーディングを 行う機会が少なく、また第二言語習得上、大きな役割をもつといわ机ている意味交渉 が期待できない課題が多いことを示唆した。また、近年の言語教育研究において口頭 コミュニケーション志向する活動の重要性が強調されつつあるとはいえ、教科書はそ れを十分反映したものとはいえないことが本研究から示唆された。真正性の高い有意 味な口頭コミュニケーションの機会を学習者に提供するためには、教科書の活動をそ のまま用いるのみではなく、学習者が自発的に言語産出を行うような「タスク的」な活 動を教師の裁量で取り入れていく必要がある。 
本研究が取り扱った 3 種類の中学校の英語教科書は、それぞれ特徵が異なり、ど のように改変を行えば真正性の高い口頭コミュニケーションを志向する活動になるの かといった端的な答えがあるわけではない。また、本研究が取り扱った教科書は日本 において大きなシェアをもつものではあったが、すべてではない。しかし、本研究が 示した、教科書に掲載されている多くの課題がもつ「真正性の高い有意味なコミュニ ケーション活動という観点から足りない点」は、教師が教室内で行う言語活動を内省 し改善するための1つの基礎資料となると考えられる。今後は筆者らも、中学の現場 で授業実践を行う教師と交流を図りながら、よりよい言語活動をどのように計画し実 践していけばよいかを考えていきたい。

\section{謝辞}

本論文の執筆にあたり、名城大学の松村昌紀先生、オークランド大学の新谷奈津子 先生に多くの貴重なコメントを頂いた。この場を借りて感謝申し上げる。なお、論文に おけるあらゆる瑕疪はすべて筆者らの責任である。

注

1. タスク関連研究のほとんどは、この基準によって採用されたタスクを用いた指導 効果を示すものであり、シラバスの評価を行うものは少ないため、タスク関連研 究が示した知見のほとんどはこの基準を満たしたタスク単体の効果であるといえ る。

2. 例えばSato and Kasahara(2015)は、従来提唱されてきたPresentation-PracticeProduction (PPP)を機軸にしつつも、Productionの活動として機械的な産出訓練 ではなく真正性の高い有意味なコミュニケーション活動を取り入れる必要性を 主張しており、PPPにタスクを取り入れたHybrid PPPを提唱している。

3. 日本経済新聞(2015)の調べによると、これらの教科書の全国シェア率はNew Horizon: 33.8\%、Sunshine: 24.8\%、New Crown: 24.2\%であり、三社で全国の $82.8 \%$ 占める。

4. 言語使用以外の評価とした場合、例えば不完全な文や誤った表現を用いて、あ るいは単語のみのやりとりでタスクを遂行してしまう学習者が出るという懸念が あるかもしれない。しかしながら、背景の節で述べた通り、TBLTでは言語使用 の正確さをタスクの達成よりも重視することはない。たとえ不完全であっても、言 語使用者として達成すべきタスクを達成したという事実を評価するからである。 ただし、不完全な文や文法的な誤りに対して教師がなにも教育的介入を行わな いことをTBLTが奨励しているわけではない。学習者の表出に現れた文法的な誤 りは、あくまで事後的に明示的・暗示的フィードバックを行うことで対応し、タスク が達成できたかどうかを主として評価を行う。

5. そもそも、ある言語形式の産出を狙った夕スクという時点で、タスクとはみなせな いという考えもある。しかしながら、中学校教科書は基本的には一つの課で学習 する言語形式が定められており、その言語形式を使うことを目標とした活動があ ることがほとんどである。したがって、ここではその活動を基にして、いかにタスク の基準を満たすような活動として機能させることができるかを重視している。 
福田純也は静岡大学教育学部特任助教である。主な研究対象は夕スクを用いた言 語指導法、第二言語習得における意識の役割などである。

田村祐は名古屋大学大学院国際開発研究科博士後期課程在籍、日本学術振興会特 別研究員 (DC2)、愛知工科大学非常勤講師である。専門は、心理言語学的アプロー チによる第二言語の文法習得研究である。

栗田朱莉は岡崎市立矢作北中学校教諭である。名古屋大学大学院国際開発研究科 博士前期課程修了、修士 (学術)。

\section{引用文献}

荒金房子. (2015).「高等学校英語教科書に見られるオーラル活動とタスクの分析」『 植草学園大学研究紀要』, 第6巻, 99-107.

Bachman, L., \& Palmer, A. (1996). Language testing in practice. Oxford, England: Oxford University Press.

Brown, H. D. (2000). Principles of language learning \& teaching (4th ed.). Clevedon, England: Multilingual Matters.

馬場哲生(編).(1997)、『英語スピーキング論——話す力の育成と評価を科学する 英語教育研究リサーチ・デザイン・シリーズ』. 東京:河源社.

Canale, M. (1983). From communicative competence to communicative language pedagogy. In J. C. Richards \& R. W. Schmidt (Eds.), Language and communication (pp. 2-27). London, England: Longman.

Canale, M., \& Swain, M. (1980). Theoretical bases of communicative approaches to second language teaching and testing. Applied Linguistics, 1, 1-47. https://doi.org/10.1093/applin/i.1.1

江草千春・横山吉樹. (2007).「英語教科書におけるコミュニケーションタスクの傾向分 析と第 2 言語習得研究からの考察」『JACET北海道支部紀要』, 第4巻, 1-23.

Ellis, R. (2003). Task-based language learning and teaching. Oxford, England: Oxford University Press.

Ellis, R., \& Shintani, N. (2014). Exploring language pedagogy through second language acquisition research. New York, NY: Routledge.

Erlam, R. (2016). 'I'm still not sure what a task is': Teachers designing language tasks. Language Teaching Research, 20, 279-299.

https://doi.org/10.1177/1362168814566087

和泉伸一. (2009).『「フォーカス・オン・フォーム」を取り入れた新しい英語教育』. 東京: 大修館書店.

Kim, Y. J. (2009). The effects of task complexity on learner-learner interaction. System, 37, 254-268. https://doi.org/10.1016/j.system.2009.02.003 
Kim, Y. J. (2012). Task complexity, learning opportunities, and Korean EFL learners' question development. Studies in Second Language Acquisition, 34, 627-658. https://doi.org/10.1017/s0272263112000368

Levelt, W. J. M. (1989). Speaking: From intention to articulation. Cambridge, MA: The MIT Press.

Long, M. H. (1985a). Input and second language acquisition theory. In S. Gass \& C. Madden (Eds.), Input in second language acquisition (pp. 379-393). Rowley, MA: Newbury House.

Long, M. H. (1985b). A role for instruction in second language acquisition: Taskbased language teaching. In K. Hyltenstam \& M. Pienemann. (Eds.), Modelling and assessing second language acquisition (pp. 77-99). Clevedon, England: Multilingual Matters.

Mackey, A. (Ed.). (2007). Conversational interaction in second language acquisition: A collection of empirical studies. Oxford, England: Oxford University Press. 松村昌紀. (2012).『タスクを活用した英語授業のデザイン』. 東京:大修館書店.

Morioka, T., Tsumura, S., \& Fukihara, A. (2015). Slow learners' attitude to reading aloud and group work. In P. Clements, A. Krause, \& H. Brown (Eds.), JALT2014 Conference Proceedings (pp. 264-271). Tokyo: JALT. Retrieved from http://jaltpublications.org/proceedings

日本経済新聞.(2015年10月30日).「三省堂の英語教科書は微減 中学教科書 シェア」『日本経済新聞』. Retrieved from http://mw.nikkei.com/sp/\#!/article/ DGXLASDG30H7Z_Q5A031C1CR8000/

Pica, T. (1992). The textual outcomes of native speaker-non-native speaker negotiation: What do they reveal about second language learning? In C. Kramsch \& S. McConnell-Ginet (Eds.), Text and context (pp. 198-237). Cambridge, MA: Heath. 佐藤臨太郎. (2014).「教授法の現状と展望」、英語教育学の今: 理論と実践の統合: 全国英語教育学会第40回研究大会記念特別誌』, pp. 284-286. Retrieved from http://www.jasele.jp/wp-content/uploads/kinen-tokubetsushi_web.pdf

Sato, R., \& Kasahara, K. (2015). TBLT or PPP; Why not “hybrid" PPP?『英語教育』10 月号. 東京:大修館書店.

Skehan, P. (1998). A cognitive approach to language learning. Oxford, England: Oxford University Press.

Swain, M. (1993). The output hypothesis: Just speaking and writing aren't enough. Canadian Modern Language Review, 50, 158-164.

臼田悦之・志村昭暢・横山吉樹・山下純一・中村洋. (2009).「教科書におけるスピー キング活動のタスク性に関する分析一中学校英語教科書の場合一」.『北海道英 語教育学会紀要』,第9巻, 17-32.

臼田悦之・志村昭暢・横山吉樹·竹内典彦・中村洋・山下純一・川上昌志. (2012).「ス ピーキング活動のタスク性調査一中学校新旧教科書を比較した場合一」『北海 道英語教育学会紀要』, 第12巻, 21-35. 